\title{
Romans 8:3-4 and God's resolution of the threefold problems of sin, the incapability of the law and the weakness of the flesh
}

\author{
Author: \\ Dirk J. Venter ${ }^{1}$ \\ Affiliation: \\ ${ }^{1}$ Faculty of Theology, \\ North-West University, \\ Potchefstroom Campus, \\ South Africa \\ Correspondence to: \\ Dirk Venter \\ Email: \\ venterd@lantic.net \\ Postal address: \\ PO Box 12, Pretoria 0184, \\ South Africa \\ Dates: \\ Received: 24 June 2013 \\ Accepted: 26 Feb. 2014 \\ Published: 12 Sept. 2014 \\ How to cite this article: \\ Venter, D.J., 2014, 'Romans \\ 8:3-4 and God's resolution \\ of the threefold problems of \\ $\sin$, the incapability of the \\ law and the weakness of the \\ flesh', In die Skriflig 48(1), \\ Art. \#1687, 7 pages. http:// \\ dx.doi.org/10.4102/ids. \\ v48i1.1687

\section{Copyright: \\ (c) 2014. The Authors. \\ Licensee: AOSIS \\ OpenJournals. This work \\ is licensed under the \\ Creative Commons} \\ Attribution License.
}

Read online:

Scan this $Q R$ code with your smart phone or mobile device to read online.
Ensuing from the argument of Romans 7:7-25, 8:3-4 presents 'the incapability of the law' as a significant part of the greater problem of sin that needed resolution. This is brought to the fore best when the opening clause of Romans 8:3 ( $\tau$ ò ... $\dot{\alpha} \delta v$ vo $\alpha$ ov) is seen as an accusative of respect with dependant clauses and not as an anacoluthon as is often supposed. This opening clause points out sin's two concomitant problems as (within this context) the primary points of reference in regard to which the claims of Romans 8:3-4 are made. Consequently, in Romans 8:3-4 Paul addresses the resolution of this threefold problem. In Romans 8:3 in particular, he argues that, through the mission of God's Son, the problems of sin and the weakness of the flesh are resolved by the condemnation of $\sin$ in the flesh (of Christ). This has the purposeresult of also resolving the problem of the incapability of the law through Christ's fulfilment of the requirement of the law $(\mathrm{Rm} 8: 4)$.

Romeine 8:3-4 en God se oplossing van die drievoudige probleem van sonde, die onvermoë van die wet en die swakheid van die vlees. In die lig van Romeine 7:7-25 impliseer 8:3-4 dat die 'onvermoë van die wet' 'n noemenswaardige deel van die groter probleem van die sonde was wat opgelos moes word. Hierdie insig tree veral duidelik

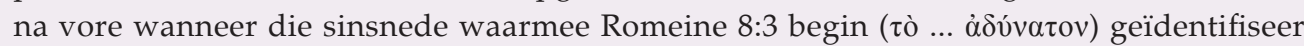
word as 'n akkusatief van opsig (met bysinne) en nie, soos dikwels veronderstel word, 'n anakoluthon nie. Die twee probleme wat met sonde gepaard gaan (die onvermoë van die wet en die swakheid van die vlees), word dus deur Paulus uitgelig as die primêre verwysingspunte ten opsigte waarvan die stellings in Romeine 8:3-4 gemaak word. In Romeine 8:3 wys Paulus dat God, deur sy Seun te stuur, die probleme van die sonde en die vlees aangespreek het deurdat die sonde in die vlees (van Christus) veroordeel is. Dit het die doel-gevolg gehad dat die meegaande probleem van die onvermoë van die wet ook opgelos is, aangesien Christus die vereiste van die wet vervul het (Rom 8:4).

\section{Introduction ${ }^{1}$}

Many have commented on the 'awkwardness' of the syntactic structure of Romans 8:3 (e.g. Jewett 2006:482). Zeller (1985:152), in addition, remarked that the accusative in the first

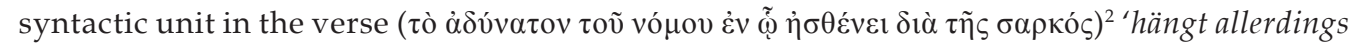
in der Luft'. Consequently, expositors have sought to explain this 'awkwardness' in different ways, including that it is an anacoluthon and/or that it is due to the incorporation of a Christological formula (Schweizer 1966:199-210). This apparent awkwardness can be better

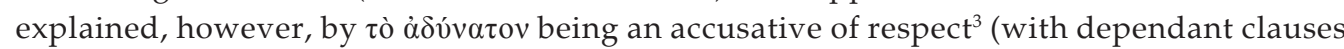

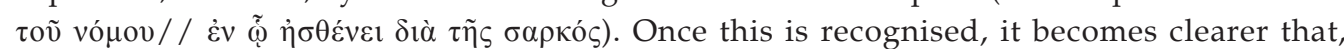
with Romans 8:3-4, Paul actually addresses the resolution of a threefold problem that stems from his argument in 7:7-25. The function of the accusative of respect is precisely to evoke this particular background context in order to argue that, through the mission of God's Son, not only the problem of (a) sin, but also the concomitant problems of (b) the weakness of the flesh and (c) the incapability of the law are resolved.

1.This article contains edited and reworked material from a paper read at the North-West University's (Potchefstroom, South Africa) 'God and cosmology' Conference in August 2012. Recognition is due to Jan van der Watt for his support and input in the preparation of the article and to Cilliers Breytenbach, Michael Wolter, Udo Schnelle, Fika Janse van Rensburg and Hermut Löhr for their comments and article and to Cilliers Breytenbach, Michae
suggestions towards the improvement of the article.

2.The appropriate translation of this phrase will be provided in the conclusion of the first section below. All excerpts in Greek are from Black et al. (1997).

3.This is a recognised use of the accusative, even if not very common in Koine Greek (Blass \& Debrunner 1961:87-88). It is sometimes also called 'accusative of reference', 'frame of reference accusative' or 'limiting accusative' (Wallace 1995:203-204). Haacker (1999:152) also identified it as such, but without providing motivation. 


\section{Is the syntactic structure of Romans 8:3 'awkward' or only exceptional?}

A popular explanation for the apparent 'awkwardness' of Romans 8:3 is that Paul incorporated the traditional Christological pattern of 'God sending his Son' into the sentence (Jewett 2006:482). ${ }^{4}$ Another explanation for the syntax, however, is that the verse opens with a (rather exceptional) accusative (

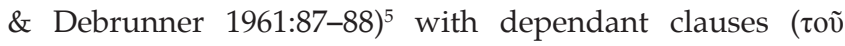

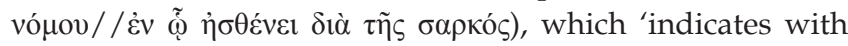
reference to what the verbal action is represented as true' (Wallace 1995:203).

Given the syntactic exceptionality of Romans 8:3, it may be helpful to identify the primary clause explicitly (consisting of only the introductory conjunction, subject, verb and object):

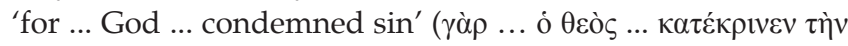
$\dot{\alpha} \mu \alpha \rho \tau i ́ \alpha v)$.

The syntax of the sentence can be illustrated by means of a diagram of the syntactic structure (Figure 1).

Thus, by providing an explanation, the conjunctive clause,

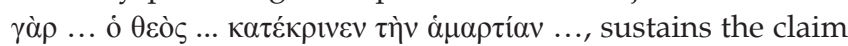
of Romans 8:2 regarding those in Christ Jesus see Wolter (2011:237) being set free from sin and death.

One needs to go back a little further to get the whole picture, however. With Romans 7:7-25, ${ }^{6}$ Paul indicted personified sin (cf. Dodson 2008:123-139) as the main culprit in the epoch before the Spirit that kept the subject from obeying God's law as she or he actually wanted to (cf. 7:19-20). ${ }^{7}$ This was the subject's problem: she or he was dominated by that terrible 'authority', sin. However, sin did not act alone. It coerced the subject's flesh and even God's law into being its collaborators in the oppression of humanity. From Romans 7:7-25, it is clear that the problem of sin is related to the two concomitant problems of the weakness of the subject's flesh and the incapability of the law. With Romans 8:3-4 Paul indicates that God has now addressed this threefold problem decisively. In order to do so, however, Paul needed to remind his readers of sin's two concomitant problems before indicating the means by which the threefold problem was resolved (in the primary clause). He achieved this by opening his sentence with an

4.Jewett (2006:482) credits Leander Keck with providing this "plausible reason for the lack of syntactic coherence' and mentions that Keck based his case on an article by Eduard Schweizer. In accord with Jewett and Keck, it should be noted that Paul uses a 'pattern' (consisting of God as subject, sending language and the Son as agent) or a 'pattern' (consisting of God as subject, sending language and the Son as agent) or
traditional theological motif rather than a developed Christological formula as the precise wording differs between occurrences (see also Gal 4:4; Jn 3:17; 1 Jn 4:9).

5.Also see Wallace (1995:203-204), who identifies Romans 10:5 as an example of this in Paul.

6. Romans 7:7-25 itself has of course been a topic of considerable scholarly debate into which it is not possible to venture here. I proffer only brief remarks that serve the purpose of sketching the background against which 8:3-4 is set (see Kümmel 1974:74-138, Lichtenberger 2004:13-105 and Packer 1999:70-81).

7.Cf. vṽv, the 'eschatological now' (Dunn 2002:415; 1998:179-181) in Romans 8:1. Further, Romans 7:25a should be taken as a proleptic exclamation which has eschatological force (Banks 1978:34-42), after which Paul returns to the subject matter of $7: 7-23$ by means of a summation in 7:25b. In Romans $8: 4-13$, Paul matter of $7: 7-23$ by means of a summation in $7: 25 \mathrm{~b}$. In Romans $8: 4-13$, Paul
characterises and describes the epoch antithetical to that of the Spirit as (the epoch of the) flesh.

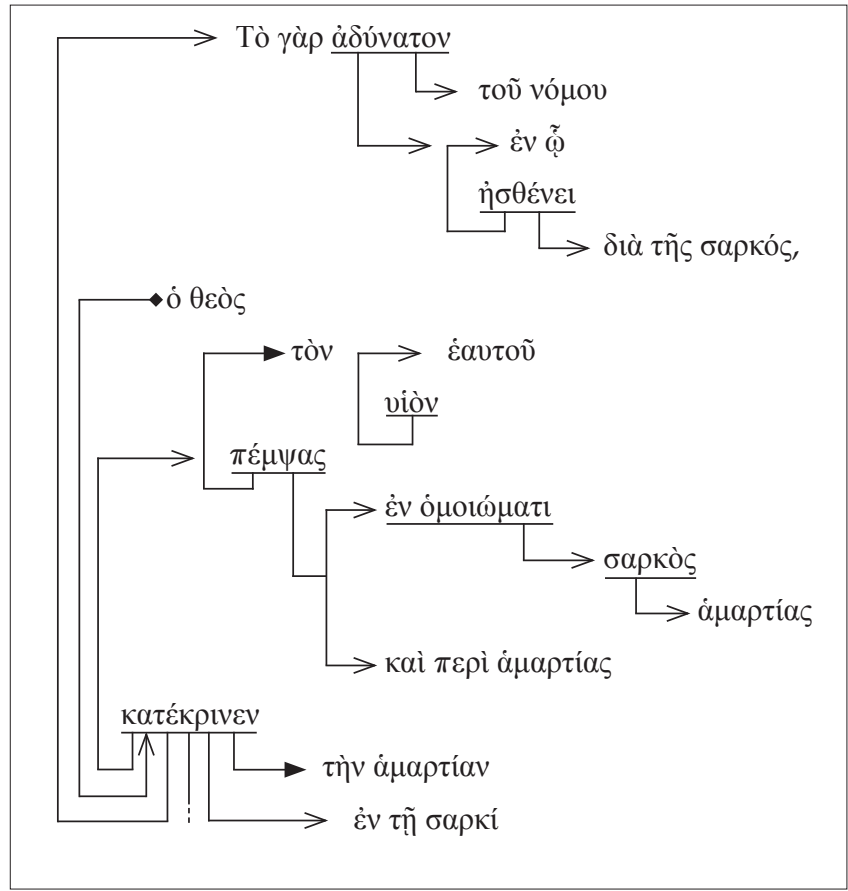

FIGURE 1: Syntactic exceptionality of Romans 8:3.

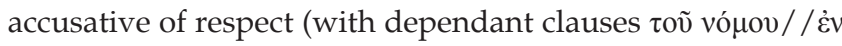

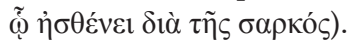

Understanding ásvivatov as such makes sense of the 'awkwardly' constructed sentence unlike Jewett's (2006) attempt to explain it as a nominative absolute in apposition to the rest of the sentence:

... because it brings the clause in apposition to God's action of condemning the flesh and thus providing a substitute for the absent main verb, to which the participle $\pi \dot{\varepsilon} \mu \psi \alpha \varsigma$ ('sent') can be subordinate. (p. 482)

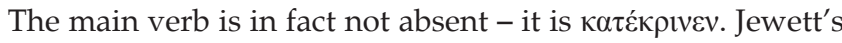
(2006) translation results in an awkward sentence indeed:

For the law [being] powerless, in that it was weak on account of the flesh, 'God, having sent his own son in the likeness of sinful flesh' and concerning sin, condemned sin in the flesh. (p. 474)

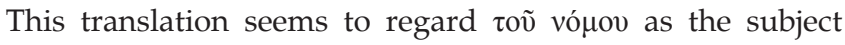
of a verbless clause, the bearing of which on the rest of the sentence is uncertain. What Jewett means by the law (or its 'incapability') being in apposition to God's condemnation of ( $\sin$ in) the flesh remains unclear. ${ }^{8}$

To posit an anacoluthon has been another common exposition of the syntax as in Moo (1996:477; also see e.g. Wilckens 1980:124; Käsemann 1980:216; and recently Hultgren 2011:298) who theorises that ' $\ldots$ as he began his

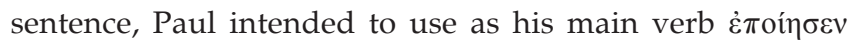
(he did,') or something equivalent to it', but in the end, he did not complete the thought this way. Although I agree that the meaning of the sentence within its context ultimately boils down to God having done what the law could not do,

8.Cf. Cranfield (1975:378) whose exposition is actually practically identical to explaining the syntax as an accusative of respect. 
positing an absent verb is syntactically unnecessary given the plausibility of $\alpha \delta \delta$ va (thus not needing an additional verb) and therefore to be avoided. ${ }^{9}$ The Greek should be rendered as follows: 'For, with reference to the incapability of the law in which ${ }^{10}$ it was weak through the flesh, God - by sending his own son in likeness to sinful flesh, and concerning $\sin ^{11}$ - condemned sin in the flesh.'

Since the law proved incapable of enabling man in his fleshly weakness to overcome sin, God had to effect not only the victory over sin, but also over sin's coercion of the flesh and the law. It was precisely with respect to the incapability of the law, weakened by the flesh, that God acted.

Before we turn to how Paul describes this action taken by God, we can conclude this section by summarising the answer to our initial question. The syntactic structure of Romans $8: 3$ is neither awkward nor does it require an anacoluthon to be posited when one realises that the opening clause ( $\tau$ ò

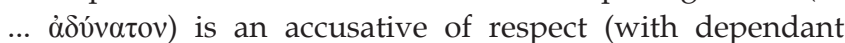
clauses). This uncommon use of the accusative does make the verse's syntactic structure exceptional.

\section{'God condemned sin' at first glance}

Paul employs the familiar forensic image (see Du Toit 2007:249-280) ${ }^{12}$ to indicate that God has decisively addressed the threefold problem of sin, the incapability of the law and the weakness of the flesh. The primary clause of Romans 8:3 pertains to the primary problem: sin. It has been (judged, pronounced guilty and) condemned by God. Since sin was condemned its rule over humanity was broken. Consequently, those who are in Christ Jesus, who live within the Spirit's sphere of authority ( $\mathrm{Rm} 8: 2)$, no longer experience or expect condemnation $(8: 1)$ since they are no longer subjects of $\sin$ (and death).

Instead, they experience freedom comparable to that of a prisoner of war and/or slave that has been manumitted..$^{13}$ Their previous slave master (personified sin) was after all taken out of the picture, because God condemned it. Since the real culprit has already been identified (cf. Rm 7:20; Byrne 1996:237), tried and condemned through the mediation of Christ (8:3), those who are in him cannot be condemned any longer (8:1). The sentence has been passed, and the case is closed.

9.Cf. Cranfield (1975:378) who finds 'no justification here for pronouncing Paul's sentence incomplete and suggesting supplements'.

10.The literal translation has been retained here although $\dot{\varepsilon} v \tilde{\omega}$ can also be appropriately translated as 'because' (Blass \& Debrunner 1961:118)

11. $\pi \varepsilon \rho i ̀ ~ \alpha \mu \alpha \rho \tau i ́ \alpha \varsigma$ is commonly also rendered: 'as a sin offering' (see the exposition below).

12.Aspects of the forensic image in Romans $8: 3$ include (a) that God acts as judge

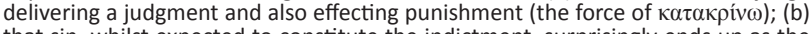
that sin, whilst expected to constitute the indictment, surprisingly ends up as the sin was personified in 7:7-25 and in effect already indicted; cf. especially 7:13 and $\sin$ was personified in 7:7-25 and in effect already indicted; cf. especially 7:13 and
17). As Haacker (1999:152) puts it: 'Anstatt die sündigen Menschen zu verdammen, 17). As Haacker (1999:152) puts it: 'Anstatt die sündigen Menschen zu verc
hat Gott die Sünde (als überpersonliche Macht vorgestellt) verdammt.'

13.The force of $\dot{\varepsilon} \lambda \varepsilon v \theta \varepsilon \rho{ }^{\prime} \omega$ in Romans 8:2 against the background of the war and slavery imagery in 7:14-25.
Three additional clauses qualify this assertion. They need to be examined closer before a picture of the meaning of 'God condemned sin' can be complete.

Firstly, the clause introduced by the accusative of respect

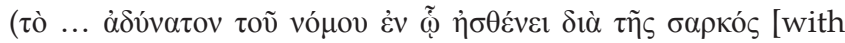
reference to the incapability of the law in which it was weak through the flesh] indicates that the two previously mentioned and related factors of the 'incapability of the law' and the fact that it was 'weak through the flesh' are, in this particular context, the primary reference points regarding which the assertion is made that 'God condemned sin'.

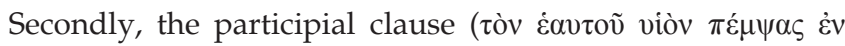

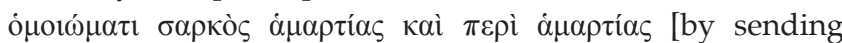
his own Son in likeness to sinful flesh and regarding sin] indicates that the means (cf. Black 1989:109-110) through which God achieved sin's condemnation was by sending his Son 'in likeness' to sin's collaborator, namely (sinful) flesh.

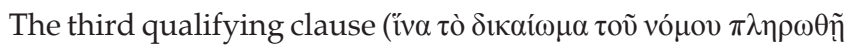

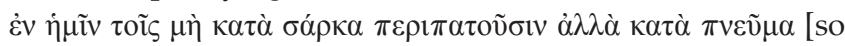
that the requirement of the law would be fulfilled in us who walk not according to the flesh but according to the Spirit] provides the purpose-result of the primary clause (why God condemned $\sin$ in the flesh). It also constitutes the resolution of the last part of the threefold problem with which Romans 8:3-4 opens. Due to the limitations of an article such as this, the implications of only the first two qualifying clauses will be discussed below whilst an exposition of Romans 8:4 (more detailed than the brief remarks already offered above) will be left for another occasion.

\section{The incapability of the law in which it was weak through the flesh}

In Paul's preceding descriptions (Rm 7:7-25), sin's terrible power to keep even those who want to obey God's law under its dominance has been related to at least two concomitant factors: the law's inability to overpower sin and to empower those who want to obey God to actually do so (7:15-23), together with man's own flesh, which had proven to be the law's Achilles heel $(7: 14,18,26)$. Consequently, it would not have been enough to address the problem of sin alone - these two related problems needed to be addressed together with sin itself. By positing the clause introduced by the accusative of respect in the beginning of his sentence, Paul is saying that God did exactly that: He addressed sin with explicit reference to its two concomitant problems - the incapability of the law and the weakness of the flesh.

In Romans 7:7-25, the law was clearly unable to effect the subject's freedom to obey God (cf. Käsemann 1980:218; Barrett 1962:153; Löhr 2007:179-180) - a freedom now experienced in the epoch of the Spirit (8:4). Personified sin has consistently proven to be too terrible and too strong. It is to this powerlessness in the face of sin that Paul refers 


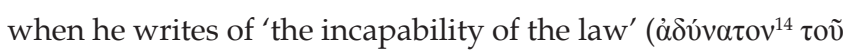
vónov; $\mathrm{Rm}$ 8:3). In the internal conflict that raged within the subject, between the antithetical authorities of Torah and sin, Torah proved to be incapable ${ }^{15}$ of empowering ${ }^{16}$ the subject to overcome sin and thus to obey God. Consequently, the law also proved incapable of giving life (for which it was actually intended, cf. Rm 7:10; Cottrell 1996:459; cf. Haacker 1999:152).

Sin also has an ally in the form of humanity's own 'flesh'

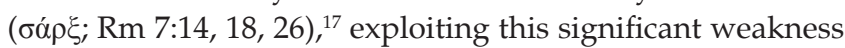
in the accoutrement of man under the old epoch. Thus the

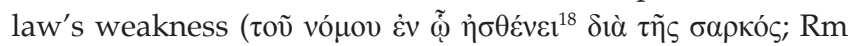
8:3) is actually Adamic humanity's weakness (cf. Wilckens 1980:124). Fleshly humanity is unable to resist the power and allure of $\sin$ (cf. $\operatorname{Rm} 7: 5,11,13-14$ ). Humanity is first and foremost prone to covetousness ( $\dot{\varepsilon} \pi \imath v \mu \mu i \alpha ; R m ~ 7: 7)-$ in disobedience of the 10th commandment and thus also disobeying the whole law (cf. Dunn 1998:98-100). Humanity's flesh is not aligned with good since 'nothing good dwells within me, that is, in my flesh' (Rm 7:18). Instead, fleshliness results in humanity doing evil, even against their will (Rm 7:19). Given this weakness of the fleshly material it had to work with, it is no wonder that Torah proved incapable of effecting humanity's actual obedience to God. ${ }^{19}$

It is important to note the epochal quality of Paul's use of $\sigma \alpha \dot{\rho} \xi$, intertwined with the concepts of weakness and being under the dominion of sin. Another aspect of Paul's concept of $\sigma \alpha ́ \rho \xi$ is its 'spatiality'. It not only denotes existence in a particular epoch, but also in a particular sphere, that is the sphere of human weakness (Byrne 1996:243). This sphere of existence will be one into which Christ will step from outside (Haacker 1999:152) whilst actually belonging to another sphere of existence himself and ultimately returning to this other sphere.

14. đóvvouov can be taken (Bauer et al 2000:22) in a more passive sense: an object is impossible (to achieve); or in a more active sense: a subject is incapable (of is impossible (to achiev); or in a more active sense a subject is incapable (of achieving an object). Although concurring with Dunn (2002:419), amongst others, that the effective distinction between these two senses is not great, an active one, which would

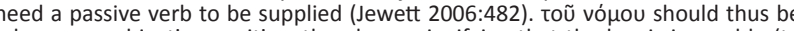
taken as a subjective genitive, the phrase signifying that the law is incapable (to achieve an object that is not spelled out here by Paul but needs to be inferred) and translated simply as 'the incapability of the law'.

15. As Paul had been at pains to emphasise in Romans 7:7-25 this does not, however mean that Torah itself is to blame for $\sin$ or is to be equated with $\sin (7: 7)$. Sin is to blame (7:13).

16.Cf. Johnson (1996:119): ' ... the difficulty with the law was not that it was wrong in what it prescribed but that it was powerless to enable humans to do what was ight, because they were "weakened by the flesh"'. Byrne (1996:235) contrast Romans 7:7-25 to 8:1-13, depicting the former as ethical "impossibility" unde (Byrne 1996:236) describes the law as 'impotent to create the righteousness it (Byrne 1996:236) describes the law as 'impotent to create the righte
demanded' (see also Witherington \& Hyatt 2004:212; Kruse 2006:125).

17.In the sense it is used here, $\sigma \alpha \dot{\rho} \xi \xi$ refers to the 'this worldly' and self-centred orientation (Moo 1996:478; Schnelle 2005:498-499) of humanity in its Adamic state - humanity prone to sin, to living out sinful passions ( $R m$ 7:5), humanity sold as a slave under the dominion of $\sin (7: 14)$ serving this slave master's decrees $(7: 25)$. It is this aspect of humanity that is always 'up to no good' (7:18). Since Adam has sinned, all his ancestors share this common proneness to sin (see Dunn 1998:62-70, 79-101; Bauer et al. 2000:914-916; Schweizer 2000:125-135).

18.Bauer et al. (2000:142) lists the possible meanings of $\alpha \dot{\sigma} \theta \varepsilon v \varepsilon \dot{\varepsilon} \omega$ as (a) to suffer a debilitating illness, be sick; (b) to experience some personal incapacity or limitation, be weak; (c) to experience lack of material necessities, be in need. In Romans 8:3, it be weak; (c) to experience lack of material necessities, be in need.
should be taken to refer not to sickness or need but to weakness.

19.Robinson (1979:94) puts it this way: 'The law was impotent because it could only be as strong as the flesh through which it had to be implemented, and the flesh was hopelessly under the power of sin.'
Importantly, Christ's boundary-crossing soteriological mission would make it possible for those freed by him to also enter into a new sphere of existence - one no longer characterised by weakness and domination under sin, but now characterised by the filial-bond-creating rule of the indwelling Spirit $(\operatorname{Rm} 8: 4,9,14)$. Although this new sphere of existence will still include Adamic bodilyness that can never be completely disengaged from the possibility to give in to fleshliness (cf. Rm 8:10,13), the inevitable dominion of $\sin$ is

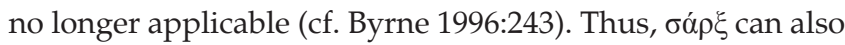
be described as the sphere of existence presided over by sin and the opposite of existing in the sphere of freedom effected by Christ and presided over by the Spirit.

Humanity's will to obey God's law is not powerful enough to overcome the alliance of the terrible power of sin with the weakness of its own flesh (Rm 7:21-23). This has left the law incapable of fulfilling its purposes described above. Consequently, 'Christ's mission and task [would be] to accomplish what the law could not do' (Fitzmyer 1993:485).

\section{The mission of the Son as the means through which God acted}

Having shown that the powerlessness of the law, weakened by man's fleshliness, was the context for God's divine intervention (Byrne 1996:236) against the dominance of sin, let us now turn to this divine intervention itself - God condemned sin in the flesh by sending his own Son.

The motif of God sending an emissary is widely attested in early Christian as well as Greco-Roman and Jewish sources (Jewett 2006:483; see Schweizer 1966:199-200). Whether its use in Romans 8:3 points to an actual pre-Pauline formula as such, as has often been argued since Schweizer's (1966:199-210) article, is debatable. For example, Moo (1996:479) considers it possible, but maintains that 'the evidence is inconclusive'. However, expositors' identification of a pre-existing formula

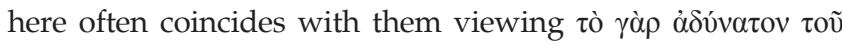
vó 1980:216), in order to explain the apparent awkwardness of the syntax. If an accusative of respect indeed explains the apparent awkwardness as this article proposes, the formula-theory in Romans 8:3 becomes largely redundant.

$\pi \varepsilon \dot{\varepsilon} \psi \alpha_{\varsigma}$ is an aorist participle acting as the verb in the

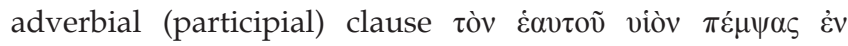

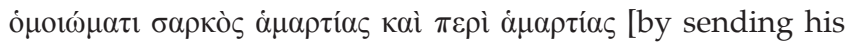
own Son in likeness to sinful flesh and regarding sin], which

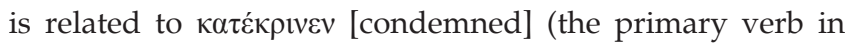
the sentence) describing the means (cf. Black 1989:109-110; Fitzmyer 1993:484) by which God condemned sin - he did it by sending his Son. To fully comprehend how the Son's mission became the means through which God condemned sin, the two additional phrases qualifying $\pi \dot{\varepsilon} \mu \psi \alpha \varsigma$ need to be taken into account.

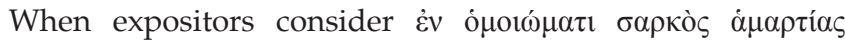
[in likeness to sinful flesh], the discussion often revolves 
around the dogmatic issue of Christ's sinlessness in spite of his complete incarnation (cf. Jewett 2006:483-484). For our purpose, it is enough to note that ó ot $_{\mu} \mu \alpha \tau$ [likeness] simultaneously denotes similarity as well as difference (Bauer et al. 2000:707; Schneider 2000:195-197; also see e.g. Wolter 2011:147; Cottrell 1996:460; Fee 1994:532) - it is 'used because of its ambivalence' (Käsemann 1980:217). A 'likeness' of someone may be a very close representation, but it still is not identical to the person him- or herself. Christ did become human ${ }^{20}$ in order to associate himself closely with and indeed represent mankind, which exhibits sinful flesh. ${ }^{21}$ However, Paul's use of ómotó $\mu \alpha \tau$ precludes the possibility of this being a complete identification to the point of Christ himself sinning. ${ }^{22}$ This being the case, the association of Christ with fleshly humankind was still sufficient for him to be effective in taking upon himself the condemnation that humankind's sin warranted. Thus Christ, by taking on humankind's flesh, that is by entering into humankind's sphere of existence in the flesh, effectively addressed the problem of sin's grasp on humankind's flesh 'from within' (Moo 1996:480). Although the redemptive effect of Christ's mission (especially his death and resurrection) potentially includes all of mankind, ultimately it is to the benefit of only those who appropriate it (participate in it) through faith (Wolter 2011:109-110).

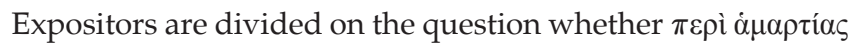
denotes merely 'regarding $\sin ^{\prime}$ (e.g. Barrett 1962:156; Cranfield 1975:382; Zeller 1985:153; Fitzmyer 1993:486) or whether it is used in the technical (sacrificial) sense of a 'sin offering' (e.g. Wilckens 1980:126-127; Käsemann 1980:216; Wright 1992:220-225; Fee 1994:533; Byrne 1996:236-237, 243; Moo 1996:480), ${ }^{23}$ though traditionally, more expositors seemed to prefer the latter. This exposition is often based on the assumption that the Septuagint uses $\pi \varepsilon \rho \dot{\alpha} \alpha \mu \alpha \rho \tau i \alpha \varsigma$ to render the Hebrew for 'as a sin offering'. ${ }^{24}$ Although Dunn (2002:422) discerns 'a strong antipathy to linking Paul's thought to sacrificial categories' on the part of some scholars, he maintains that such sacrificial allusions would be natural and unremarkable to people living within a 1st-century context. Dunn also expounds the basic theology behind the phrase (interpreted sacrificially). Since 'the only remedy for flesh's incorrigible weakness in the hands of sin is its death',

20. Paul's description is not docetic, implying that the Son only appeared to be in a form like that of sinful flesh, but was actually born as a human' (Fitzmyer 1993:485; cf. Gl 4:4).

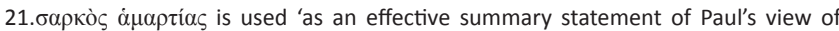
the fallen human condition' denoting the 'epochal reality' of mankind in its unredeemed state (Dunn 2002:421). This relates to Paul's Adam Christology (see Schnelle 2005:437)

22.2 Corinthians 5:21 is a clear example of Paul pointing out Christ's own sinlessness within the context of his substitutionary role. Thus this question should not too easily be relegated to being a post-Pauline dogmatic concern since it is in fact already present in Paul's theology (if germinally at least; cf. Käsemann 1980:217 also cf. Bauer et al. 2000:707).

23.Wolter (2011:106-107) mentions $\pi \varepsilon \rho \grave{~} \alpha \mu \alpha \rho \tau i ́ \alpha \varsigma$ (Rm 8:3) under a paragraph that discusses the sacrificial background to the redemptive effect (Heilswirkung) of Christ's death but concludes that, in the context of 8:3, it must remain open whether it denotes 'as a sin offering' or 'as a consequence of $\sin ^{\prime}$ (wegen der sünde).

24.For example Leviticus 5:6-7, 11; 16:3, 5, 9; Numbers 6:16; 7:16; 2 Chronicles 29:23-24; Nehemiah 10:33; Ezekiel 42:13; 43:19 (Dunn 2002:422; cf. Wolter 2011:106). Moo (1996:480) indicates that 44 of the 54 Septuagint occurrences of $\pi \varepsilon \rho i$ ó $\mu \alpha \rho \tau$ ías pertains to sacrifice. See, however, the critique of Breytenbach (1993:73-74). the sin offering, a substitute being of flesh itself, effects God's condemnation of sin through the destruction of its flesh (i.e. its death). This is applied metaphorically to the death of Christ, which, similar to a sin offering, effects freedom from sin and its dire consequences.

Breytenbach (1993:73-75), however, states a few reasons why 'sin offering' is not the appropriate rendering in Romans 8:3 nor in 2 Corinthians 5:21. In the immediate context, $\dot{\alpha} \mu \alpha \rho \tau i ́ \alpha$ consistently refers to ' $\mathrm{sin}^{\prime}$ ', making it unnatural to read it as 'sin offering' in this one instance only. Breytenbach also finds it doubtful that, even in the LXX rendition of Leviticus, $\dot{\alpha} \mu \alpha \rho \tau i ́ \alpha$ refers to anything else than simply ' $\sin$ '. He substantiates this with the fact that $\pi \varepsilon \rho$ ì $\alpha \mu \alpha \rho$ ía does not fixedly refer to 'sin offering' in the Greek pseudepigrapha, Philo or Josephus either. With Breytenbach, Schnelle (2005:445) is also of the opinion that the connotation here is probably 'a general image of atonement, not the specific sacrificial cult of the Old Testament'. He (Schnelle 2005:446) continues by pointing out that '... it is much more likely that the Greek idea of the substitutionary death of the righteous, whose death effects the expiation/taking away of sin, is the starting point for the formation of this tradition'. ${ }^{25}$ Thus, at this stage, the question still seems to be undecided though Breytenbach's point of view seems to be gaining ground.

Is there any significance to Paul's use of $\dot{\varepsilon} \alpha v \tau o \tilde{v}$ in the motif of God sending his Son? Might there be a reason for him to emphasise that God sent his own Son? Cottrell (1996:460) and others have stated that the description of Jesus' mission

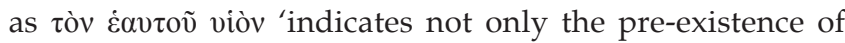
Christ but his divine nature as well'. Though both these concerns, together with the concept of incarnation, may logically be inferred from the phrase, ${ }^{26}$ none of these seem to be foremost in Paul's argument (cf. Fee 1994:530). Two

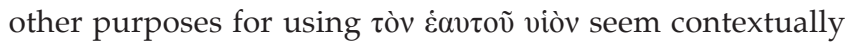
more appropriate.

Firstly, the phrase emphasises the extent to which God involved himself personally in the once and for all resolution of the problem of sin. No longer would a regular substitute suffice. God now took personal initiative and became intimately involved by sending his own Son. As Fitzmyer (1993) puts it:

The emphatic phrase ... highlights the divine relationship of Jesus to the Father and the divine origin of the task to be accomplished by one in close filial relationship with God. (p. 484)

A result of this emphasis is that the emotional impact of the statement is increased (cf. Dunn 2002:421): It was not some abstract third party who would become the substitute but God's very own beloved Son.

25.Diese Tendenz, Sühne vom Kult abzukoppeln, wird durch die Hellenisierung des Judentums verstärkt, zumal der Gedanke eines Todes 'für' in der Kaizerzeit verbreitet war, ohne an Tempelriten gebunden zu sein' (Breytenbach 1993:75). Early Jewish-Christianity read particularly Isaiah 53 in the light of the Greek concept Early Jewish-Christianity read particularly Isaiah 53 in the light of the Greek concep of the substitutionary death of a righteous person, and according to Breytenbach (1993:77-78), this is the more likely 'hintergrund of Paul's theology of Christ's
atonement as opposed to a sacrificial allusion.

26.Cf. Fossum (1992:133, 135), Schnelle (2005:442) and also Byrne (1996:243), who bases his inference on the parallels of $\mathrm{Gl} 4: 4-5$, Philippians 2:6 and 2 Corinthians 8:9. See, however, Dunn's (2002:420-421) critique. 
Secondly, the emphasis here anticipates a point that Paul will soon make in the context of Romans 8:14-30. Ultimately, God will have many (adopted) 'sons' (viós;

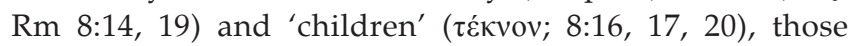
'predestined to be conformed to the image of his Son

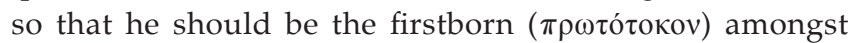
many brothers' (8:29). The unique and foundational role of Jesus Christ, the original and archetypal Son, thus seems to be anticipated here through the emphasis that He is $\tau$ òv

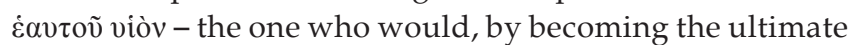
sin offering or righteous substitute, not only make possible our adoption (Rm 8:14-16) but also our 'walk not according to the flesh but according to the Spirit' (8:4).

It should be clear that Paul's Adam Christology (particularly Rm 5:12-21) underpins this whole motif. Adam has by his transgression begun an epoch in which sin and death dominate humankind. As such, he is the originator and representative of this epoch in which humankind corporately exists and participates, transgresses and ultimately dies. However, in this way, Adam also paved the way for an antithetical prototype whereby Christ's salvific work expunges the culpability of those who are 'in him'. Christ has become the 'new Adam', the originator and representative of a new epoch for mankind, based upon his death and resurrection, in which those who believe in him now corporately exist.

From Romans 5:16-18 it is clear that, whereas existence within the paradigm of Adam means corporately participating in his sin ( $\dot{\alpha} \mu \alpha \rho \tau \alpha \dot{v} \omega, \pi \alpha \rho \dot{\alpha} \pi \tau \omega \mu \alpha)$,

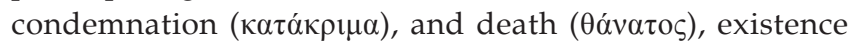
within the paradigm of Christ means corporately participating in the acquittal $(\delta i \kappa \alpha i \omega \mu \alpha)$ and righteousness

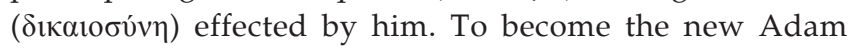
(originator and representative of mankind in a new epoch), Christ has taken on the likeness of the first Adam, closely associating himself with sinful humankind, being 'in the flesh' himself in order to effectively deal with the problem of sin right where it resided (Schnelle 2005:499). Whilst in most New Testament references to God sending his Son, the point is primarily the incarnation (Moo 1996:479), in Romans 8:3 substitutionary (possibly sacrificially) and participatory aspects are added to the incarnational. Since Christ (the new Adam) collectively carried the just punishment for mankind's sin, it is as if those who 'are in him' were actually there themselves and have (in him) already been punished, making unmerited any subsequent punishment for sins already condemned (cf. Rm 8:1).

\section{A more complete picture of 'God condemned sin'}

That finally brings us back to the primary clause of Romans

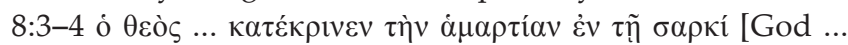
condemned sin in the flesh]. Paul's meaning should be clear by now. Through an image that is not only forensic, but also substitutionary, Paul asserts that God has effectively addressed the problems of humankind's weak flesh that is dominated by $\sin$ by means of the mission of his Son into the sphere of 'sinful flesh'. As the first Adam initiated an epoch of sin dominated flesh, Jesus, the second Adam, was sent to conclude it (cf. Rm 5:12-21; cf. Fitzmyer 1993:487). By becoming the Godsend representative of mankind-under-the-sway-of-sin (without actually bowing before sin himself) and by bringing the ultimate sacrifice (at least proverbially), ${ }^{27}$ Christ bore the condemnation of humankind's sin in his body when he died on the cross. Thus, all sin was collectively condemned by God in the flesh of Jesus Christ, and he bore that condemnation out in the destruction of his flesh (his death). Those who partake of this reality through their participation or inclusion 'in Christ' by faith (cf. Rm 1:16-17; 3:22-24, 26) can boldly proclaim with Paul that 'there is now no condemnation' for me (cf. 8:1)!

\section{Conclusion}

Ensuing from the argument of Romans 7:7-25, 8:3-4 presents 'the incapability of the law' as a significant part of the greater problem of sin that needed resolution. This is brought to the fore best when the opening clause of

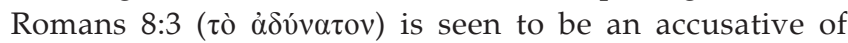

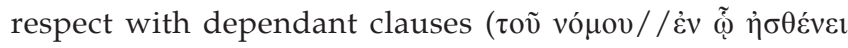
$\delta i \alpha ̀ ~ \tau \tilde{\Upsilon} \varsigma \sigma \alpha \rho \kappa o ́ \varsigma)$, which points out sin's two concomitant problems as (within this context) the primary points of reference in regard to which the claims of 8:3-4 are made.

Overpowering $\sin$ (personified as slave master in the background context of Romans 7:7-25), through the weakness of humanity's fleshliness, coerced even the law of God into serving its own purposes. In the face of terrible sin, the law proved incapable of dealing with sin decisively and effectively, of empowering those who wished to obey it to actually do so and of nullifying death as sin's inevitable outcome. Put positively: The law proved incapable of bringing life to those who would obey the law.

However, through the mission of his Son, God decisively and effectively addressed the threefold problems of sin, the weakness of the flesh and the incapability of the law. Sin and flesh were addressed through the condemnation of $\sin$ in the flesh of Christ with the result that those 'in Christ' are assured that they are freed from the prospect of condemnation (Rm 8:1-2). The incapability of the law was also addressed in that the mission of the Son fulfilled the requirement of the law with reference to those who walk according to the Spirit ( $\mathrm{Rm} 8: 4)$.

\section{Acknowledgements Competing interests}

The author declares that he has no financial or personal relationship(s) which may have inappropriately influenced him in writing this article.

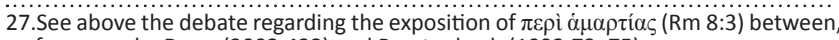
for example, Dunn (2002:422) and Breytenbach (1993:73-75). 


\section{References}

Banks, R., 1978, 'Romans 7:25a: An eschatological thanksgiving', Australian Biblical Review 26, 34-42.

Barrett, C.K., 1962, A commentary on the epistle to the Romans, Adam \& Charles Black, London.

Bauer, W., Danker, F.W., Arndt, W.F. \& Gingrich, F.W. (eds.), 2000, A Greek-English Lexicon of the New Testament and Other Early Christian Literature, 3rd edn. University of Chicago Press, Chicago. (Electronic edn., Logos Bible Software).

Black, M., 1989, Romans, 2nd edn., Eerdmans, Grand Rapids.

Black, M., Martini, C.M., Metzger, B.M. \& Wikgren, A., 1997, The Greek New Testament, United Bible Societies, Federal Republic of Germany. (Electronic edn., Logos Bible Software).

Blass, F. \& Debrunner, A., 1961, A Greek grammar of the New Testament and other early Christian literature, transl. R.W. Funk, The University of Chicago Press, Chicago.

Breytenbach, C., 1993, 'Versöhnung, Stellvertretung und Sühne: Semantische und traditionsgeschichtliche Bemerkungen am Beispiel der paulinischen Briefe', New traditionsgeschichtliche Bemerkungen am Beispiel der paulinischen Briefe, $N$,
Testament Studies 39, 59-79. http://dx.doi.org/10.1017/S0028688500020294

Byrne, B., 1996, Romans, The Liturgical Press, Collegeville.

Cottrell, J., 1996, Romans, vol. 1, College Press, Joplin.

Cranfield, C.E.B., 1975, A critical and exegetical commentary on the epistle to the Romans, T \& T Clark, Edinburgh.

Dodson, J.R., 2008, The 'powers' of personification: Rhetorical purposes in the book of Wisdom and the letter to the Romans, Walter de Gruyter, Berlin. http://dx.doi. org/10.1515/9783110209778

Du Toit, A., 2007, 'Forensic metaphors in Romans and their soteriological significance', in C. Breytenbach \& D.S. du Toit (eds.), Focusing on Paul: Persuasion and theological design in Romans and Galatians, pp. 249-280, Walter de Gruyter, Berlin.

Dunn, J.D.G., 1998, The theology of Paul the apostle, Eerdmans, Grand Rapids.

Dunn, J.D.G., 2002, Romans, Word Incorporated, Dallas. (Electronic edn., Logos Bible Software).

Fee, G.D., 1994, God's empowering presence: The Holy Spirit in the letters of Paul, Hendrickson, Peabody.

Fitzmyer, J.A., 1993, Romans: A new translation with introduction and commentary, Doubleday, New York.

Fossum, J., 1992, 'Son of God', in D.N. Freedman (ed.), The Anchor Bible dictionary, vol. 6, pp. 128-137, Doubleday, New York. (Electronic edn., Logos Bible Software).

Haacker, K., 1999, Der Brief des Paulus an die Römer, Evangelische Verlagsanstalt, Leipzig.

Hultgren, A.J., 2011, Paul's letter to the Romans: A commentary, Eerdmans, Grand Rapids.
Jewett, R., 2006, Romans: A commentary, Fortress, Minneapolis.

Johnson, L.T., 1996, Reading Romans: A literary and theological commentary, Crossroad, New York.

Käsemann, E., 1980, Commentary on Romans, transl. G.W. Bromiley, SCM Press, London.

Kruse, C.G., 2006, 'Paul, the law and the Spirit', in S.E. Porter (ed.), Paul and his theology, pp. 109-130, Brill, Leiden.

Kümmel, W.G., 1974, Römer 7 und das Bild des Menschen im Neuen Testament: Zwei Studien, Kaiser, München.

Lichtenberger, H., 2004, Das Ich Adams und das Ich der Menschheit: Studien zum Menschenbild in Römer 7, Mohr Siebeck, Tübingen.

Löhr, H. 2007, 'Paulus und der Wille zur Tat: Beobachtungen zu einer frühchristlichen Theologie als Anweisung zur Lebenskunst', Zeitschrift für die neutestamentliche Wissenschaft und die Kunde der älteren Kirche 98(3/4), 165-188.

Moo, D.J., 1996, The epistle to the Romans, Eerdmans, Grand Rapids.

Packer, J.I., 1999, 'The "wretched man" revisited: Another look at Romans 7:14-25', in S.K. Soderlund \& N.T. Wright (eds.), Romans and the people of God: Essays in honor of Gordon D. Fee on the occasion of his 65th birthday, pp. 70-81, Eerdmans, Grand Rapids.

Robinson, J.A.T., 1979, Wrestling with Romans, SCM Press, London

Schneider, J., 2000, 'ó $\mu$ oi $\omega \mu \alpha$ ', in G. Kittel \& G. Friedrich (eds.), Theological dictionary of the New Testament, transl. G.W. Bromiley, vol. 5, pp. 191-198, Eerdmans, Grand Rapids. (Electronic edn., Logos Bible Software).

Schnelle, U., 2005, Apostle Paul: His life and theology, transl. M.E. Boring, Baker Academic, Grand Rapids.

Schweizer, E., 1966, 'Zum traditiongeschichtlichen Hintergrund der "Sendungsformel" Gal 4,4f. Rm 8,3f. Joh 3,16f. 1 Joh 4,9', Zeitschrift für die neutestamentliche Wissenschaft und die Kunde der älteren Kirche 57(3/4), 199-210.

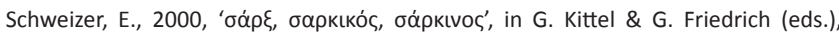
Theological dictionary of the New Testament, transl. G.W. Bromiley, vol. 7, pp. 97-151, Eerdmans, Grand Rapids. (Electronic edn., Logos Bible Software).

Wallace, D.B., 1995, Greek grammar beyond the basics: An exegetical syntax of the New Testament, Zondervan, Grand Rapids.

Wilckens, U., 1980, Der Brief an Die Römer, Benziger, Zürich.

Witherington, B. \& Hyatt, D., 2004, Paul's letter to the Romans: A socio-rhetorical commentary, Eerdmans, Grand Rapids.

Wolter, M., 2011, Paulus: Ein Grundriss seiner Theologie, Neukirchener Verlagsgesellschaft, Neukirchen-Vluyn.

Wright, N.T., 1992, The climax of the covenant: Christ and the law in Pauline theology, Fortress, Minneapolis.

Zeller, D., 1985, Der Brief an die Römer, Pustet, Regensburg. 